\title{
Increasing the Production Potential of an Agricultural Enterprise by Increasing the Motivation of its Employees
}

\author{
S.V. Yekimov ${ }^{1}$, V.A. Tkachenko ${ }^{2}$, S.N. Voit $^{2}$, K.V. Zavgorodniy ${ }^{2}$, and O.I. Zayats ${ }^{3}$ \\ ${ }^{1}$ Publishing House "Education and Science", 18100 Praha, Czech Republic \\ ${ }^{2}$ Alfred Nobel University, 49000 Dnipro, Ukraine \\ ${ }^{3}$ Uzhorod National University, 88000 Uzhhorod, Ukraine
}

\begin{abstract}
The production potential of an agricultural enterprise is a set of interacting production, labor and other resources at the disposal of this enterprise. The qualitative and quantitative parameters of these resources, as well as their degree of integration interaction, largely determine the production capabilities of an agricultural enterprise as an economic entity. At the same time, in our opinion, the production potential determines only the potential ability of an enterprise to produce goods or services , and therefore, in our opinion, it cannot be a fully objective indicator of its usefulness. The production potential of the enterprise can be fully realized, provided that its characteristics and its components meet certain parameters of the manufactured products.In the conditions of market competition, success can be achieved only if there is a high quality of the products produced.The production potential to a certain extent depends on the quality of products that are produced by the enterprise. The agricultural sector of the economy is labor-intensive, so the quality of manufactured products, and therefore the production potential of an agricultural enterprise, depends on successful motivation to work.
\end{abstract}

\section{Introduction}

In a market economy, the greatest success in competition is achieved by enterprises that quickly respond to changes in customer preferences, take into account trends in the influence of external factors, and effectively adapt the company's development strategy in accordance with their dynamics. Thus, in our opinion, the problem of studying the potential capabilities of the enterprise from the point of view of the efficiency of the enterprise is important. An organization can have labor, production, financial, and other types of potential .

Each enterprise has a set of intangible and material resources, taking into account the goals and objectives that it faces, these resources determine the production potential of the organization.

According to Kramarenko, I. (2019), Bryla, Pawel. (2018) the production potential of an enterprise is determined by the system unity of factors that allow the enterprise to perform certain functions while achieving its goals. 
According To Kochetkov, Olexii \& Afanasova, Julia. (2020) the production potential of an enterprise is a relationship that takes place during economic activity in the process of achieving optimal production results with the effective use of available material and human resources.

According to Akbasheva, D. M. \& Goguev, R. A. \& Salpagarova, A. R. \& Arova, A. \& Urusova, L.. (2020), Urbancova, Hana. (2018) the production potential of the enterprise is the basis of the overall economic potential of the organization, its presence determines the ability to conduct production activities.

The Authors Symons, Leslie. (2019) define production potential as a cumulative set of resources, but do not take into account the existence of relationships and their participation in the production process. Other authors Kharenko, A. O. \& Korotieiev, M. A. \& Bortnyk, T. I.. (2016) define production potential as the ability of an enterprise to produce material values using available resources.

According to Burlankov, S. \& Kuzmin, S.. (2018), Balko, Sergej \& Aliev, Sabri. (2016) understand the production potential of an enterprise as having the potential to produce competitive products through the use of available labor and material and technical resources.

According to Averkyna, Maryna \& Shmyhelskyi, Yurii. (2020) production potential is an integral indicator of production and economic activity and contains qualitative and quantitative components. The main purpose of the enterprise's production potential is to generate new values, and its components should be correlated with the requirements for the products produced.

The authors Sokolova, E. V. \& Zakharova, T. I.. (2020) define the production potential of an enterprise as a set of production assets of an enterprise .

According To Chuhlib, V.. (2020), Volkova, Nelia \& Neberja, Karina \& Lesheva, Alina. (2019) the competitive production potential of an enterprise is directly related to its production capacity and is a system of using the available resources of the enterprise in a certain way to achieve its goals. These resources include human resources, managerialorganizational and material-technical subsystems, production base, and the ability to produce products of the required quantity and quality

According to Davydenko, Nadiia \& Skrypnyk, Halyna \& Titenko, Zoya. (2019) the production potential of an enterprise is a complex , multi-component, inter-integrated, dynamic system that consists of separate interrelated elements that take part in the production of the necessary competitive products.

A number of authors Ermakov, O. \& Velichko, O. \& Bohach, L. \& Nagorny, Vjacheslav. (2018), Kuzmenko, L. V.. (2015), Prokopyshak, V. B.. (2016), Smulka, O.. (2020) identifies the production and economic potentials of the enterprise.

Efficiency of using the production potential of the enterprise's ability to produce a certain amount of products over a certain period of time.

According to Bulkin, S.. (2019) the efficiency of production capacity can be considered in two dimensions: economic and technological.

According To Davydenko, Nadiia \& Skrypnyk, Halyna \& Titenko, Zoya. (2019) the main problem of determining the production potential of an enterprise is that it is a dynamic system in which its individual components have a mutual impact on each other, while their properties and operating conditions change. Therefore, it is difficult to determine the regularities of the evolution of the production potential as a whole system from the behavior of individual elements of the production potential. 


\section{Methods}

In carrying out this research, we used an analytical method of research, which in turn made it possible to study the scientific problems considered in this work in their development and unity. Taking into account the tasks and goals of the research work, the structural and functional approach of scientific research was used. The use of which made it possible to study a number of issues related to increasing the production potential of an agricultural enterprise through increasing the motivation of its employees.

\section{Results}

Based on the analysis, we came to the conclusion that the production potential of the enterprise is a set of interacting labor, production and other resources at the disposal of the enterprise. Quantitative and qualitative parameters of these resources and their level of integration interaction determine the production capabilities of the enterprise as an economic entity.

However, in our opinion, the production potential determines only the ability of an enterprise to produce goods or services, and therefore cannot be an objective measure of its usefulness. The production potential of an enterprise can be fully realized if the characteristics and composition of its components correspond to certain parameters of the manufactured products.

In our opinion, the impact of product quality on the production potential depends to a certain extent on the quality of products produced by the enterprise, but this issue has not yet been sufficiently studied by researchers.

The category "product quality" is inextricably linked with the production activities of the enterprise. Both consumers and producers face it. Product quality is an important indicator that guides the buyer when purchasing a product. It serves as a material basis through which consumers can meet their needs.

The higher the quality level, the more material opportunities a society has for its social and economic development.

In a competitive market, you can only succeed if you have high quality products. In the international and domestic markets, first of all, products of good quality are in demand. Bad products can't always be sold even at low prices. Therefore, in our opinion, the problem of product quality has a great impact on the production potential of the enterprise.

Enterprises in the agricultural sector of the economy widely use manual labor, this primarily concerns vegetable growing, gardening and animal husbandry. Therefore, to ensure quality, employees need to be motivated, in other words, for the competitive and successful functioning of an agricultural enterprise, a set of ways and methods is necessary that the company's management could improve the efficiency of staff work. Agricultural enterprises often pay their employees small salaries, and this in turn does not allow them to achieve the maximum level of realization of the potential of labor resources. A person who receives a meager payment does not have an interest is not particularly interested in working with full efficiency.

The specifics of the agricultural enterprise has a number of features:

1) most of the work is performed outdoors regardless of climate and weather conditions;

2) the work is seasonal, there is a time interval between getting the finished result and the production process. The demand for labor resources is maximum during the harvest period and during sowing operations;

3 ) the results of production activities are largely dependent on weather and climatic conditions;

4) low-skilled labor is often used in agriculture. 
5) agricultural products require special conditions for transportation and storage.

In our opinion, various surcharges and bonuses can be used to provide material incentives for working at an agricultural enterprise. The success of the agricultural sector depends on increasing labor productivity. However, employees may not always be interested in increasing it. They fear that the employer may increase the rate of output, and thus the employee will lose part of his salary.

Thus, we believe that management needs to take a balanced approach to the issue of increasing the output rate.

In our opinion, improving the living standards of rural residents can be important for motivating the work of agricultural workers. This includes opening new schools, pre-school institutions, medical centers, cultural and sports institutions, trade enterprises, public catering and consumer services. Often, rural residents have to spend time traveling to the city to address their urgent needs.

The importance for motivation of labour resources in rural areas is the provision of workers housing.

\section{Discussion}

The efficiency of functioning of agricultural enterprises currently depends significantly on the formation and ability to use the production potential. At the same time, not rational use of material resources of the enterprise, ill-conceived methods and forms of attracting labor resources, as well as disproportions between the components that make up the production potential lead to its reduction. In the context of the crisis caused by the covid-19 pandemic, many agricultural enterprises have reduced sales of finished products, there is a reduction in employees and a decrease in their productivity.

Increasing the production potential makes it possible to achieve more efficient use of interacting production resources and, as a result, increase the volume of agricultural production and better meet the needs of consumers.

Efficiency of application of production capacities in the medium and long term, in our view, should be based on the manufacturing of innovative, resource-saving, energy-saving and environmentally friendly technologies, and application systems to manage quality of products.

Achieving greater labor productivity in agricultural enterprises is possible through the introduction of new innovative technologies. And this requires training and retraining of employees of agricultural enterprises.

Agriculture is the basis of the material and social well-being of the state, the guarantor of the country's food security. In our opinion, it should be a priority industry for the introduction of modern innovative technologies.

In our opinion, this requires an appropriate targeted state policy aimed at supporting the agricultural sector of the economy.

\section{Conclusions}

Increasing the efficiency of using the production potential of an agricultural enterprise helps to increase labor productivity, sales of products and helps to attract investment resources on favorable terms.

Production potential is important in improving the competitiveness of the organization in the market, taking into account its objective assessment, it is possible to develop a more effective strategy for the development of production. The importance and role of the production potential of an agricultural enterprise in the process of social production is in 
continuous development. Production potential determines the opportunities for scientific and technological progress.

Having the production potential allows the company to set up production that will be competitive in the market, to carry out sustainable development in a dynamically changing internal and external economic environment.

\section{References}

1. D.M. Akbasheva, R.A. Goguev, A.R. Salpagarova, A. Arova, L. Urusova, Accounting at an agricultural enterprise, Scientific development trends and education (2010)

2. Maryna Averkyna, Yurii Shmyhelskyi, Market Infrastructure (2020)

3. Sergej Balko, Sabri Aliev, Improving the management of agricultural enterprises potential. Interactive science (2016)

4. Pawel Bryla, Profitability in Polish Agricultural Enterprises (2018)

5. S. Bulkin, Agrosvit, 24, 112 (2019)

6. S. Burlankov, S. Kuzmin, Vestnik of the Plekhanov Russian University of Economics, 6, 77 (2018)

7. V. Chuhlib, Agrosvit, 13-14, 90 (2020)

8. Nadiia Davydenko, Halyna Skrypnyk, Zoya Titenko, Investment attractiveness of agricultural enterprises, 128, 242 (2019)

9. O. Ermakov, O. Velichko, L. Bohach, Vjacheslav Nagorny, Financial and credit activity: problems of theory and practice, 3, 162 (2018)

10. A.O. Kharenko, M.A. Korotieiev, T.I. Bortnyk, Husbandry product distribution by agricultural enterprises, 184 (2016)

11. Olexii Kochetkov, Julia. Afanasova, The economic discourse, 2(12), 117 (2020)

12. I. Kramarenko, Efektyvna ekonomika, 12, 54 (2019)

13. L.V. Kuzmenko, Production potential formation at an agricultural enterprise, 164, 205 (2015)

14. V.B. Prokopyshak, Scientific Bulletin of UNFU, 26, 162 (2016)

15. O. Smulka, Agrarian Economy, 13, 45 (2020)

16. E.V. Sokolova, T.I. Zakharova, Resource Potential for Sustainable Development of Agricultural Enterprises (2020)

17. Leslie Symons, Agricultural Enterprises and Systems (2019)

18. Nelia Volkova, Karina Neberja, Alina Leshheva, Pryazovskyi Economic Herald, 5 (2019)

19. Hana Urbancova, Agricultural Enterprises in the Czech Republic (2018) 